\title{
Dichloroiodoisocyanuric Acid: A New Reagent for Regioselective Coiodination of Alkenes and Iodination of Activated Arenes"
}

\author{
Rodrigo da Silva Ribeiro, Pierre M. Esteves* and Marcio C. S. de Mattos* \\ Instituto de Química, Universidade Federal do Rio de Janeiro, CP 68545, 21945-970 Rio de Janeiro-RJ, Brazil
}

\begin{abstract}
O ácido dicloro-iodo-isocianúrico foi preparado em $93 \%$ de rendimento através do aquecimento do ácido tricloro-isocianúrico com 1,05 equiv. mol de iodo. Esse novo reagente se mostrou bastante eficiente para a iodação regiosseletiva de arenos ativados. Os alquenos reagem com o ácido dicloroiodo-isocianúrico na presença de solventes nucleofílicos oxigenados (água, álcoois, ácido acético) para gerar, respectivamente, iodoidrinas, $\beta$-iodoéters e $\beta$-iodoacetatos em menos de um minuto de reação e em alto grau de regiosseletividade. Enol-éteres levam à formação regiosseletiva dos iodo-dialquilacetais correspondentes. Os resultados experimentais juntamente com os cálculos por DFT mostraram que, para reações com sistemas insaturados, o ácido dicloro-iodo-isocianúrico é mais reativo do que o ácido triiodo-isocianúrico.
\end{abstract}

Dichloroiodoisocyanuric acid was prepared in $93 \%$ by heating trichloroisocyanuric acid with 1.05 mol equiv. of iodine. This new reagent is very efficient for regioselective electrophilic iodination of activated arenes. Alkenes react with dichloroiodoisocyanuric acid in the presence of oxygenated nucleophiles (water, alcohols, and acetic acid), leading to the corresponding iodohydrins, $\beta$-iodoethers and $\beta$-iodoacetates with reaction times of less than one minute and with a high degree of regioselectivity. Enol ethers resulted in the regioselective formation of the corresponding iodine-dialkylacetals. Experimental results and DFT calculations showed that dichoroiodoisocyanuric acid is more reactive with unsaturated systems than triiodoisocyanuric acid.

Keywords: alkenes, arenes, electrophilic addition, electrophilic aromatic substitution, halogenation

\section{Introduction}

Iodo-organic compounds are valuable and versatile synthetic intermediates that have found diverse applications in polymer chemistry, pharmacology, medicine, etc. ${ }^{1}$ Aside from their principal application in organic synthesis, ${ }^{2}$ the discovery of the bioactivity of naturally organic iodides ${ }^{3}$ has increased the interest in such compounds. The introduction of an iodine atom into organic molecules is frequently an important step in organic synthesis as the iodine atom can easily be replaced by another group in a nucleophilic process, free radical substitution ${ }^{4}$ or a transition metal catalyzed reaction, for example, the Heck and related Pd catalyzed cross-couplings. ${ }^{5}$ However, the poor electrophilicity of molecular iodine, compared with molecular bromine and chlorine, makes direct iodination

\footnotetext{
*e-mail: pesteves@iq.ufrj.br, mmattos@iq.ufrj.br

\#Dedicated to Prof. José Barluenga for his many achievements in synthetic organic chemistry.
}

difficult in many cases. ${ }^{6}$ Hence, many different synthetic methods (direct and indirect), or their improvements, have been reported for the preparation of iodo compounds.?

Recently, we have introduced trihaloisocyanuric acids (Figure 1) as efficient halogenating reagents for organic compounds. Thus the cohalogenation of alkenes (halogenation in the presence of a nucleophilic solvent ${ }^{8}$ ) with trichloroisocyanuric (TCCA), ${ }^{9}$ tribromoisocyanuric (TBCA),${ }^{10}$ or triiodoisocyanuric (TICA) ${ }^{11}$ acids led to the formation of $\beta$-halo-substituted alkanes in high regioselectivity. These reagents have also proved to be useful for the halogenation of activated ${ }^{12,13}$ and deactivated ${ }^{14}$ arenes, $\beta$-dicarbonyl compounds, ${ }^{15}$ and halofluorination of alkenes. ${ }^{16}$ The trihaloisocyanuric acids containing different halogen atoms are also of great interest and in a previous study we showed that bromodichloroisocyanuric acid (BDCCA) is also a very good regioselective brominating agent. ${ }^{17}$

Herein we introduce the preparation of a new compound, dichloroiodoisocyanuric acid (DCICA, Figure 1), and 
investigate its application towards alkene coiodination and arene iodination reactions.

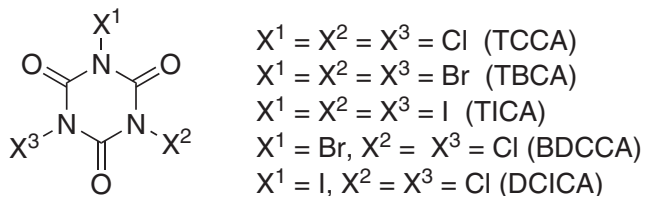

Figure 1. The trihaloisocyanuric acids.

\section{Results and Discussion}

Dichloroiodoisocyanuric acid was prepared in 93\% yield from the commercially available trichloroisocyanuric acid (Scheme 1). The reaction was performed in a sealed tube by heating TCCA with 1.05 mol equiv. of $\mathrm{I}_{2}$ at $170{ }^{\circ} \mathrm{C}$ for $18 \mathrm{~h}$, followed by distillation of $\mathrm{ICl}$ and another heating for $24 \mathrm{~h}$ at $220^{\circ} \mathrm{C}$.
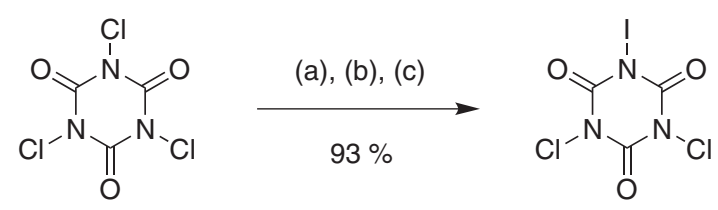

(a) $\mathrm{I}_{2} / 170^{\circ} \mathrm{C} / 18 \mathrm{~h}$; (b) distillation of ICl; (c) $220^{\circ} \mathrm{C} / 24 \mathrm{~h}$

Scheme 1. Preparation of dichloroiodoisocyanuric acid.

The scope of the coiodination reactions using DCICA in oxygenated nucleophilic solvents was explored with simple alkenes (cyclohexene, 1-methylcyclohexene, styrene, $\alpha$-methylstyrene, and 1-octene) and with activated alkenes (enol ethers, such as butyl vinyl ether, dihydropyran and 1-methoxycyclohexene), being the results shown in Table 1. The reactions were carried out in less than 1 min using $2 \mathrm{mmol}$ of alkene and $2 \mathrm{mmol}$ of DCICA at room temperature and led to the vicinal iodo functionalized products.

The reaction of alkenes with an equimolar amount of DCICA in the presence of alcohols $(\mathrm{MeOH}, \mathrm{EtOH}$, and ${ }^{\mathrm{PrOH}}$ ), aqueous acetone and acetic acid/acetic anhydride resulted in the respective $\beta$-iodoethers, iodohydrins, and $\beta$-iodoacetates. The reactions with styrene, $\alpha$-methylstyrene, and 1-methylcyclohexene were highly regioselective, and products were formed in accordance with Markovnikoff additions; no regioisomers could be detected on analyzing the crude reaction products by HRGC-MS, ${ }^{1} \mathrm{H}$ and ${ }^{13} \mathrm{C}$ NMR spectroscopy. Enol ethers also produced the corresponding iodo-dialkylacetals in a regioselective manner. As previously observed in similar reactions, ${ }^{28}$ exceptions were observed in the reactions using 1-octene where a mixture of regioisomers was produced, with the primary iodide being preferentially formed.
Furthermore, as previously observed in the reactions with bromodichloroisocyanuric acid, ${ }^{17}$ no chlorinated products that could arise from electrophilic chlorine transfer from DCICA were detected by the analytical methods employed.

High trans-stereoselectivity was also observed for additions to cyclohexene, 1-methycyclohexene and dihydropyran, as can be seen by the values of the vicinal coupling constants for the methine hydrogen atoms CHOR and $\mathrm{CHI}$ in the iodohydrin and $\beta$-iodoethers derived from cyclohexane (Table 2). In these cases the obtained values of $J$ greater than $9.0 \mathrm{~Hz}$ indicate they are in an antiperiplanar position. ${ }^{29}$ Furthermore, the additional vicinal couplings depicted in Table 2 support the trans-selectivity of the reaction. In the case of the reaction of DCICA with 1-methylcyclohexene, the iodohydrin formed shows the methine CHI hydrogen with vicinal couplings $J_{\text {ax-ax }} 12.1 \mathrm{~Hz}$ and $J_{\text {ax-eq }} 4.3 \mathrm{~Hz}$, clearly indicating that the iodine is in the equatorial position. ${ }^{29}$

Iodination of some activated arenes were carried out at room temperature using equimolar amounts of the substrate and DCICA in acetonitrile (Table 3). After work-up, the corresponding iodinated products were obtained in excellent yields and with high regioselectivity, as observed the formation of 4-substituted monoiodo arenes and 1-iodo2-methoxynaphthalene. Even weakly activated arenes, such as toluene, were iodinated after $1.5 \mathrm{~h}$. Diiodination products can also be obtained by using 2 mol equiv. of DCICA in the case of durene. On the other hand, non-activated arenes, e.g. benzene reacted very slowly. Once again, no chlorinated products could be detected by HRGC-MS and ${ }^{1} \mathrm{H}$ and ${ }^{13} \mathrm{C}$ NMR spectroscopy.

In previous studies using triiodoisocyanuric acid (TICA, Figure 1), the iodination reactions of the same arenes ${ }^{12}$ or the coiodination of the same alkenes ${ }^{11}$ were found to require longer reaction times than those observed in this present study with DCICA, as shown in Table 4.

Comparing the reactivity of DCICA with TICA towards iodenium ion $\left(\mathrm{I}^{+}\right)$transfer to alkenes and arenes, we observed that DCICA is far more reactive. This could be explained in terms of the greater electronegativity of chlorine in relation to iodine. This would result in the N-I bond of DCICA being more electrophilic in comparison to the N-I bonds of TICA (Figure 2).

In order to better understand the reactivity differences between TICA and DCICA, we have performed DFT calculations on these structures and on their complexes with ethylene and benzene. All calculations were performed at M06-2X/6-311++G(d,p)//M06-2X/6-311++G(d,p) level using the program Gaussian $09 .{ }^{35}$ Charges were computed using the CHELPG scheme, ${ }^{36}$ considering the radii of $2.20 \AA$ for iodine. ${ }^{37}$ 
Table 1. Coiodination of alkenes with DCICA and oxygenated nucleophiles

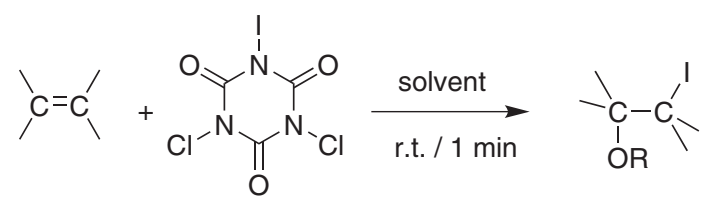

\begin{tabular}{|c|c|c|c|c|}
\hline Alkene & Product & Solvent & Yield / $(\%)^{\mathrm{a}}$ & Ref. to product \\
\hline & & $\mathrm{MeOH}$ & 99 & 18 \\
\hline & & $\mathrm{EtOH}$ & 98 & 19 \\
\hline & & ${ }^{\mathrm{i}} \mathrm{PrOH}$ & 98 & 19 \\
\hline & & $\mathrm{MeOH}$ & 75 & 20 \\
\hline & & ${ }^{i} \mathrm{PrOH}$ & 76 & 21 \\
\hline & & $\mathrm{MeOH}$ & $80^{\mathrm{b}}$ & 22 \\
\hline & & $\begin{array}{c}\mathrm{H}_{2} \mathrm{O} / \mathrm{Me}_{2} \mathrm{CO} \\
(5: 1)\end{array}$ & 87 & 19 \\
\hline & & $\begin{array}{c}\mathrm{H}_{2} \mathrm{O} / \mathrm{Me}_{2} \mathrm{CO} \\
(5: 1)\end{array}$ & 99 & 23 \\
\hline & & $\begin{array}{c}\mathrm{H}_{2} \mathrm{O} / \mathrm{Me}_{2} \mathrm{CO} \\
(5: 1)\end{array}$ & 83 & 18 \\
\hline & & $\begin{array}{c}\mathrm{H}_{2} \mathrm{O} / \mathrm{Me}_{2} \mathrm{CO} \\
(5: 1)\end{array}$ & 42 & 24 \\
\hline & & $\begin{array}{c}\mathrm{H}_{2} \mathrm{O} / \mathrm{Me}_{2} \mathrm{CO} \\
(5: 1)\end{array}$ & $85^{\mathrm{b}}$ & 23 \\
\hline & & $\begin{array}{c}\mathrm{HOAc} / \mathrm{Ac}_{2} \mathrm{O} \\
(1: 1)\end{array}$ & 89 & 25 \\
\hline & & $\mathrm{MeOH}$ & 99 & 11 \\
\hline & & $\mathrm{MeOH}$ & 99 & 26 \\
\hline & & $\mathrm{MeOH}$ & 51 & 27 \\
\hline
\end{tabular}

aield of pure product based on alkene. ${ }^{\text {b} F o r m e d ~ a l o n g ~ w i t h ~} \mathrm{ca}$. 20\% of the regioisomer (by HRGC-MS). 
Figure 3 shows the optimized geometries, with selected geometric parameters. One can observe that the charge on the iodine atoms is slightly more positive and the N-I bond is larger for DCICA than for TICA, which suggests

Table 2. Coupling constants for the iodo-alkoxycyclohexanes prepared

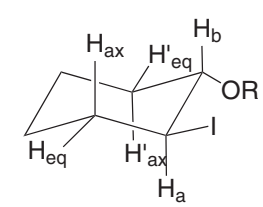

\begin{tabular}{lccc}
\hline Coupling & \multicolumn{3}{c}{$J / \mathrm{Hz}$} \\
\cline { 2 - 4 } & $\mathrm{R}=\mathrm{H}$ & $\mathrm{R}=\mathrm{Me}$ & $\mathrm{R}={ }^{\mathrm{i}} \mathrm{Pr}$ \\
\hline $\mathrm{H}_{\mathrm{a}}-\mathrm{H}_{\mathrm{b}}$ & 9.8 & 9.0 & 8.9 \\
$\mathrm{H}_{\mathrm{a}}-\mathrm{H}_{\text {eq }}$ & 4.4 & 3.8 & 4.4 \\
$\mathrm{H}_{\mathrm{a}}-\mathrm{H}_{\mathrm{ax}}$ & 12.3 & 9.0 & 10.9 \\
$\mathrm{H}_{\mathrm{b}}-\mathrm{H}_{\text {eq }}$ & 4.4 & 4.1 & 4.4 \\
$\mathrm{H}_{\mathrm{b}}-\mathrm{H}^{\prime}{ }_{\mathrm{ax}}$ & 9.8 & 9.0 & 8.9 \\
\hline
\end{tabular}

its higher electrophilicity. However, more differences are found on their $\pi$-complexes with ethylene (Figure 4) and benzene (Figure 5). The DCICA is more closely attached to the olefin in relation to TICA and the dissociation enthalpies of these complexes are $6.8 \mathrm{kcal} \mathrm{mol}^{-1}$ and $5.6 \mathrm{kcal} \mathrm{mol}^{-1}$ for DCICA and TICA, respectively. This shows that the interaction of ethylene with DCICA is slightly stronger than with TICA, reflecting the higher electrodeficiency of its compared to TICA. On the other hand, the enthalpy for dissociation of both complexes of DCICA and TICA with benzene is $6.7 \mathrm{kcal} \mathrm{mol}^{-1}$.

We have also carried out calculations of the transition states for $\mathrm{I}^{+}$transfer of both reagents and the results are shown in Figure 6. One can see from the enthalpies of activation that the chlorine within the isocyanuric moiety leads to a decrease in the activation barrier from $20.2 \mathrm{kcal} \mathrm{mol}^{-1}$ (TICA) to $17.7 \mathrm{kcal} \mathrm{mol}^{-1}$ (DCICA). This can be explained by the greater ability of the chlorine atoms in DCICA to stabilize the negative charge formed

Table 3. Iodination of activated arenes with DCICA

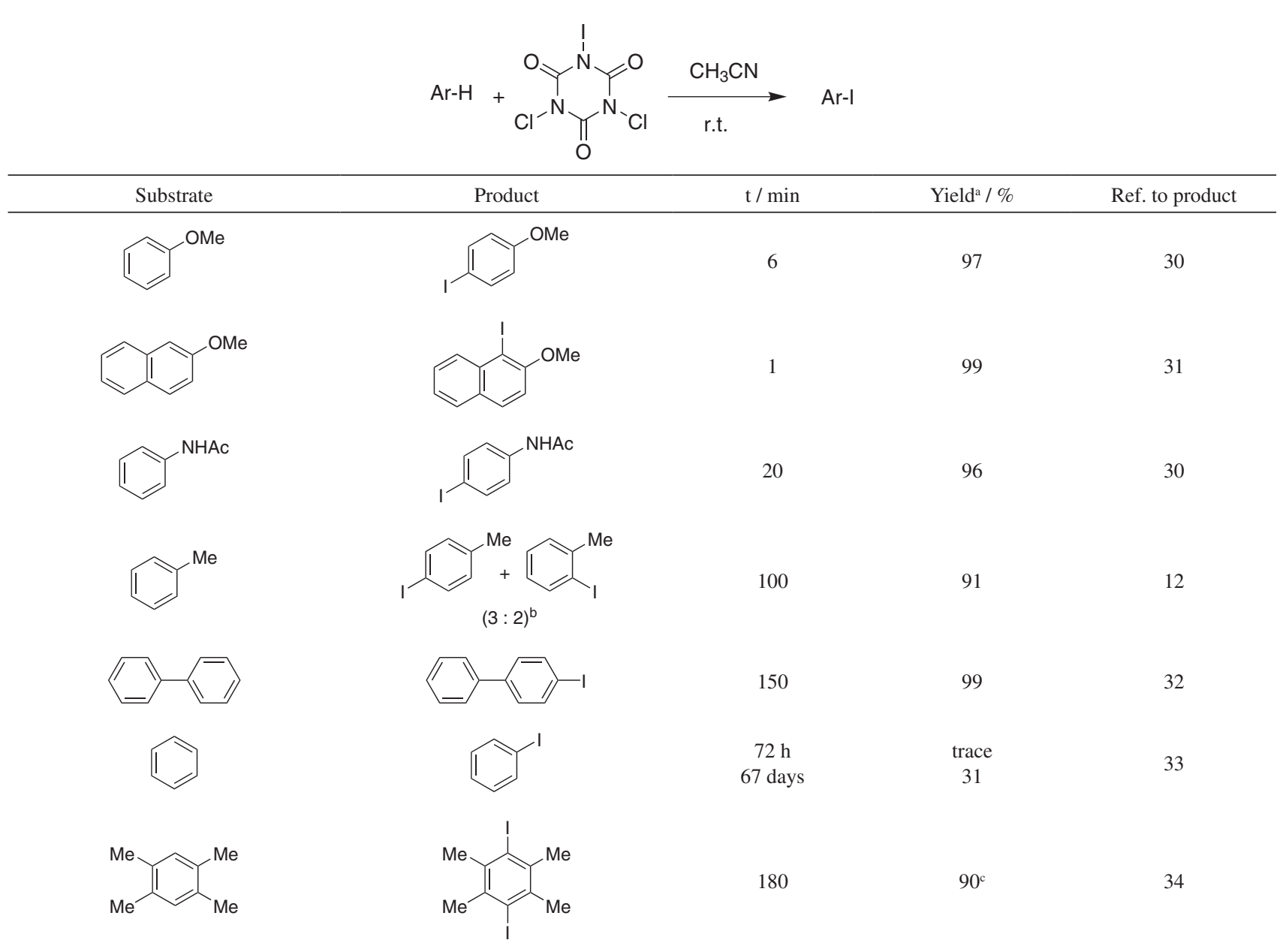

${ }^{a}$ Yield of pure product based on arene. ${ }^{b}$ Determined by HRGC-MS. ${ }^{~}$ Reaction using 2 mol equiv. of DCICA. 
Table 4. Comparison of electrophilic iodination reactions using DCICA and TICA



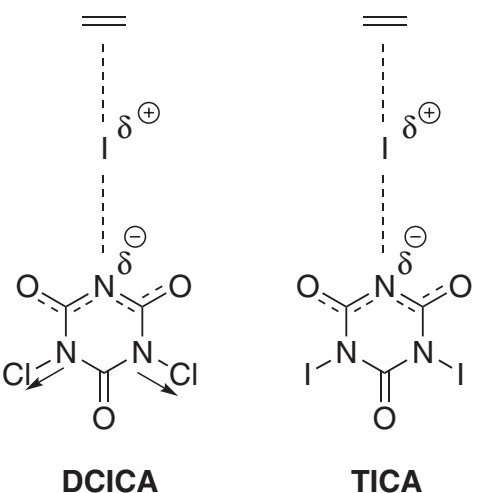

Figure 2. Transfer of I+ from DCICA and TICA to an unsaturated system.

in the transition state of $\mathrm{I}^{+}$transfer in relation to TICA. These findings are also in agreement with the experimental results, which indicate DCICA being the most reactive of the two compounds.

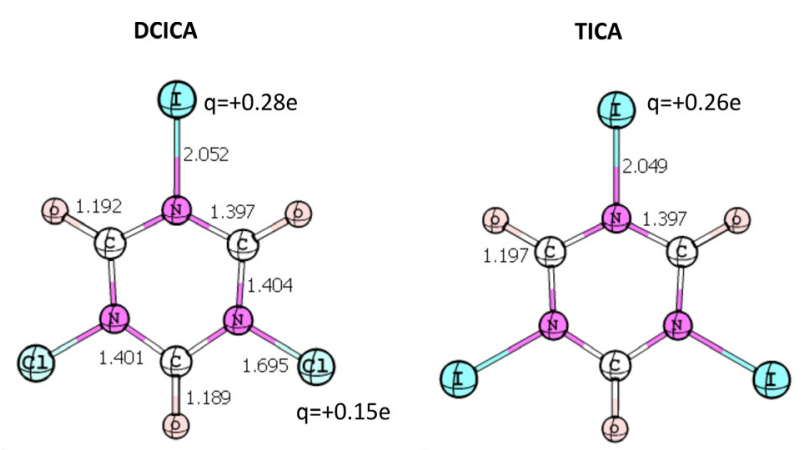

Figure 3. Optimized geometries with selected geometric parameters for DCICA and TICA obtained at M06-2X/6-311++G(d,p) level.

In summary, we have reported here the preparation of dicloroiodoisocyanuric acid and its higher reactivity toward some unsaturated hydrocarbons as compared to triiodoisocyanuric acid. This reagent proved to be very 
useful for the iodination of alkenes and arenes in clean and fast reactions.


Figure 4. $\pi$-Complexes between ethylene and DCICA and TICA obtained at M06-2X/6-311++G(d,p) level.
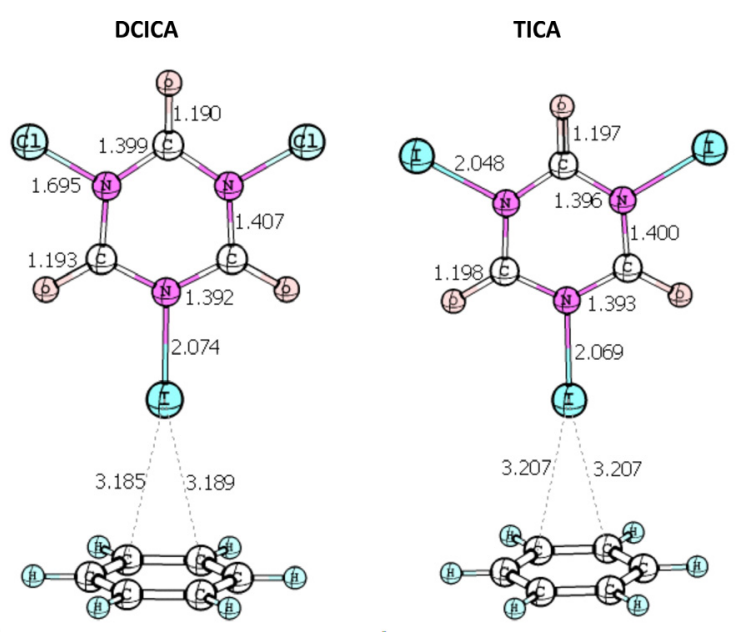

Figure 5. $\pi$-Complexes between benzene and DCICA and TICA obtained at M06-2X/6-311++G(d,p) level.

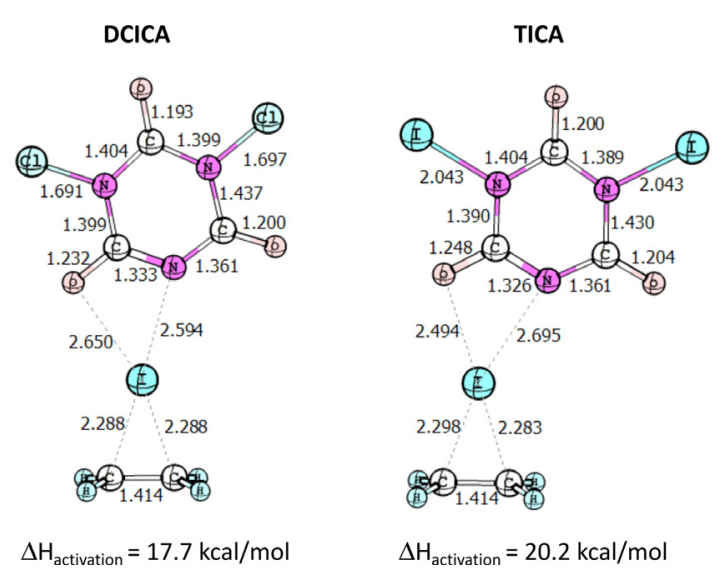

Figure 6. Transition states for $\mathrm{I}^{+}$transfer of DCICA and TICA obtained at M06-2X/6-311++G(d,p) level.

\section{Experimental}

\section{General}

Trichloroisocyanuric acid (commercial grade, 98\%), and other chemicals and solvents were used as received. The ${ }^{1} \mathrm{H}$ and ${ }^{13} \mathrm{C}$ NMR spectra were recorded on a Bruker AC-200 (200 MHz and $50 \mathrm{MHz}$, respectively) spectrometer in $\mathrm{CDCl}_{3}$ or DMSO- $d_{6}$ solutions with TMS as internal standard. ${ }^{13} \mathrm{C}$ MAS-NMR spectrum was obtained on a Bruker DRX300 spectrometer (75MHz). High-resolution gas chromatography (HRGC) was performed on a HP-5890-II gas chromatograph with FID using a $30 \mathrm{~m}$ (length), $0.25 \mathrm{~mm}$ (ID), and $25 \mu \mathrm{m}$ (phase thickness) RTX-5 capillary column and $\mathrm{H}_{2}$ (flow rate $50 \mathrm{~cm} \mathrm{~s}^{-1}$ ) as carrier gas (split: 1:10). HRGC-MS analyses were performed on a Shimadzu GCMS-QP2010S gas chromatograph with electron impact $(70 \mathrm{eV})$ by using a $30 \mathrm{~m}$ DB-5 silica capillary column. IR spectra were recorded on a Nicolet 740 FT-IR spectrometers $(\mathrm{NaCl}$ film). Elemental analysis was determined on a Perkin-Elmer 2400 apparatus. All reactions involving DCICA must be performed in the absence of light.

\section{Dicloroiodoisocyanuric acid (DCICA)}

Crushed iodine (26.65 g, $105 \mathrm{mmol})$ and trichloroisocyanuric acid $(23.25 \mathrm{~g}, 100 \mathrm{mmol})$ were added to a $100 \mathrm{~cm}^{3}$ sealed tube and heated in a sand bath at $170{ }^{\circ} \mathrm{C}$. After $18 \mathrm{~h}$, the ICl produced was distilled off under reduced pressure and the sealed tube was heated again at $220{ }^{\circ} \mathrm{C}$ during $24 \mathrm{~h}$. Evaporation of $\mathrm{ICl}$ under reduced pressure and heating gave a solid that was crushed and washed with $\mathrm{CH}_{2} \mathrm{Cl}_{2}$ to produce dichloroiodoisocyanuric acid (DCICA) as a beige solid (30.13 g) in 93\% yield. This reagent must be stored in the dark as some decomposition occurs in the presence of light; $\mathrm{mp}>300{ }^{\circ} \mathrm{C}$. Anal. Calc. for $\mathrm{C}_{3} \mathrm{~N}_{3} \mathrm{O}_{3} \mathrm{Cl}_{2} \mathrm{I}$ : C, 11.11, N, 12.96. Found: C, 10.74, N, 12.48. ${ }^{13} \mathrm{C}$ MAS-NMR: $\delta 150.1 \mathrm{ppm}$. IR $v_{\max } / \mathrm{cm}^{-1}: 1837$, 1716, 1697, 1662, 1457, 1362, 762, 534.

General procedure for coiodination of alkenes with DCICA in oxygenated nucleophilic solvents

To a stirred solution of the alkene $(2 \mathrm{mmol})$ in an appropriate solvent $\left(10 \mathrm{~cm}^{3}\right.$ of acetone $/ 2 \mathrm{~cm}^{3}$ of $\mathrm{H}_{2} \mathrm{O}$ for iodohydrins, or $10 \mathrm{~cm}^{3}$ of alcohols for $\beta$-iodoethers, or $5 \mathrm{~cm}^{3}$ acetic acid $/ 5 \mathrm{~cm}^{3} \mathrm{Ac}_{2} \mathrm{O}$ for $\beta$-iodoacetates), DCICA $(2 \mathrm{mmol}$ ) was added at room temperature and in the absence of light. After $1 \mathrm{~min}, \mathrm{CH}_{2} \mathrm{Cl}_{2}\left(10 \mathrm{~cm}^{3}\right)$ was added, cyanuric acid was filtered off and the resulting solution was treated 
with $10 \%$ aq. $\mathrm{NaHSO}_{3}\left(50 \mathrm{~cm}^{3}\right)$. The aqueous phase was washed with $\mathrm{CH}_{2} \mathrm{Cl}_{2}\left(2 \times 10 \mathrm{~cm}^{3}\right)$, the organic extract was dried (anhydrous $\mathrm{Na}_{2} \mathrm{SO}_{4}$ ) and filtered. The solvent was evaporated on a rotatory evaporator to give the product.

General procedure for iodination of activated arenes with DCICA

To a stirred solution of the arene $(2 \mathrm{mmol})$ in acetonitrile $\left(10 \mathrm{~cm}^{3}\right)$, was added DCICA $(2 \mathrm{mmol})$ at room temperature and in the absence of light. The reaction was monitored by HRGC-MS and after the specified time showed in Table $3, \mathrm{CH}_{2} \mathrm{Cl}_{2}\left(10 \mathrm{~cm}^{3}\right)$ was added, cyanuric acid was filtered off and the resulting solution was treated with $10 \%$ aq. $\mathrm{NaHSO}_{3}\left(60 \mathrm{~cm}^{3}\right)$. The aqueous phase was extracted with $\mathrm{CH}_{2} \mathrm{Cl}_{2}\left(2 \times 10 \mathrm{~cm}^{3}\right)$, the combined organic extract was washed with $\mathrm{H}_{2} \mathrm{O}\left(60 \mathrm{~cm}^{3}\right)$, dried (anhydrous $\mathrm{Na}_{2} \mathrm{SO}_{4}$ ) and filtered. The solvent was evaporated in a rotatory evaporator to give the product.

\section{Supplementary Information}

Experimental procedure, data spectra and spectra of synthesized compounds are available free of charge at http://jbcs.sbq.org.br

\section{Acknowledgments}

The authors thank CNPq, CAPES, and FAPERJ for the financial support.

\section{References}

1. David, G.; Boyer, C.; Tonnar, J.; Ameduri, B.; LacroixDesmazens, P.; Boutevin, B.; Chem. Rev. 2006, 108, 3936; Adam, M. J.; Wilbur, D. S.; Chem. Soc. Rev. 2005, 34, 153; Maziere, B.; Loc'h, C.; Curr. Pharm. Des. 2001, 7, 1931.

2. Bohlmann, R. In Comprehensive Organic Synthesis, Vol 6; Trost, B. M.; Fleming, I., eds.; Pergamon Press: Oxford, 1991, p. 203.

3. Gribble, G. W.; Prog. Chem. Org. Nat. Prod. 2010, 91, 1; Gribble, G. W.; Chemosphere 2003, 52, 289.

4. Spargo, P. L.; Contemp. Org. Synth. 1994, 1, 113.

5. Trzeciak, A. M.; Ziólkowski, J. J.; Coord. Chem. Rev. 2007, 251,1281

6. de Mattos, M. C. S.; Sanseverino, A. M.; J. Chem. Res. (S) 1994, 440.

7. Stavber, S.; Jereb, M.; Zupan, M.; Synthesis 2008, 1487.; Kolvani, E.; Ghorbani-Choghamarani, A.; Salehi, P.; Shirini, F.; Zolfigol, M. A.; J. Iran. Chem. Soc. 2007, 4, 126; de Souza, S. P. L.; da Silva, J. F. M.; de Mattos, M. C. S.; Quim. Nova 2006,
29, 1061; Villegas, R. A. S.; Santo Jr., J. L. E.; de Mattos, M. C. S.; de Aguiar, M. R. M. P.; Guarino, A. W. S.; J. Braz. Chem. Soc. 2005, 16, 565.

8. Rodrigues, J.; Dulcere, J.-P.; Synthesis 1993, 1177; Sanseverino, A. M.; da Silva, F. M.; Jones Jr., J.; de Mattos, M. C. S.; Quim. Nova 2001, 24, 637; da Silva, F. M.; Jones Jr., J.; de Mattos, M. C. S.; Curr. Org. Synth. 2005, 2, 393.

9. Mendonça, G. F.; Sanseverino, A. M.; de Mattos, M. C. S.; Synthesis 2003, 45; de Souza, A. V. A.; Mendonça, G. F.; Bernini, R. B.; de Mattos, M. C. S.; J. Braz. Chem. Soc. 2007, 18, 1575.

10. de Almeida, L. S.; Esteves, P. M.; de Mattos, M. C. S.; Synlett 2006, 1515.

11. Ribeiro, R. S.; Esteves, P. M.; de Mattos, M. C. S.; Tetrahedron Lett. 2007, 48, 8747.

12. Ribeiro, R. S.; Esteves, P. M.; de Mattos, M. C. S.; J. Braz. Chem. Soc. 2008, 19, 1239.

13. Mendonça, G. F.; de Mattos, M. C. S.; Quim. Nova 2008, 31, 798; de Almeida, L. S.; Esteves, P. M.; de Mattos, M. C. S.; Synthesis 2006, 221.

14. Mendonça, G. F.; Senra, M. R,; Esteves, P. M.; de Mattos, M. C. S.; Appl. Catal., A 2011, 401, 176; da Ribeiro, R. S.; Esteves, P. M.; de Mattos, M. C. S.; Synthesis 2011, 739; de Almeida, L. S.; Esteves, P. M.; de Mattos, M. C. S.; Tetrahedron Lett. 2009, 50, 3001; Mendonça, G. F.; Magalhães, R. R.; de Mattos, M. C. S.; Esteves, P. M.; J. Braz. Chem. Soc. 2005, 16, 695.

15. Mendonça, G. F.; Sindra, H. C.; de Almeida, L. S.; Esteves, P. M.; de Mattos, M. C. S.; Tetrahedron Lett. 2009, 50, 473.

16. Crespo, L. T. C.; Ribeiro, R. S.; de Mattos, M. C. S.; Esteves, P. M.; Synthesis 2010, 2379.

17. de Almeida, L. S.; Esteves, P. M.; de Mattos, M. C. S.; Synlett 2007, 1687.

18. Barluenga, J.; Rodriguez, M. A.; Campos, P. J.; J. Chem. Soc., Perkin Trans. 1 1990, 2807.

19. Villegas, R. A. S.; Santo Jr., J. L. E.; de Mattos, M. C. S.; de Aguiar, M. R. M. P.; Guarino, A. W. S.; Catal. Commun. 2007, $8,97$.

20. Cambie, R. C.; Hayward, R. C.; Roberts, J. L.; Rutledge, P. S.; J. Chem Soc., Perkin Trans. 1 1974, 1858.

21. Villegas, R. A. S.; Santo Jr., J. L. E.; Sanseverino, A. M.; de Mattos, M. C. S.; de Aguiar, M. R. M. P.; Guarino, A. W. S.; Synth. Commun. 2005, 35, 1627.

22. Davidson, R. I.; Kropp, P. J.; J. Org. Chem. 1982, 47, 1904.

23. Villegas, R. A. S.; de Aguiar, M. R. M. P.; de Mattos, M. C. S.; Guarino, A. W. S.; Barbosa, L. M.; Assumpção, L. C. F. N.; J. Braz. Chem. Soc. 2004, 15, 150.

24. Sanseverino, A. M.; de Mattos, M. C. S.; Synthesis 1998, 1584.

25. de Mattos, M. C. S.; Sanseverino, A. M.; J. Chem. Res. 2004, 638.

26. Jereb, M.; Zupan, M.; Stavber, S.; Green Chem. 2005, 7, 100.

27. D’Auria, M.; D’Onofrio, F.; Piancatelli, G.; Scettri, A.; Synth. Commun. 1982, 12, 1127. 
28. Wengert, M.; Sanseverino, A. M.; de Mattos, M. C. S.; J. Braz. Chem. Soc. 2002, 13, 700; de Souza, S. P. L.; da Silva, J. F. M.; de Mattos, M. C. S.; J. Braz. Chem. Soc. 2003, 14, 832; Sanseverino, A. M.; de Mattos, M. C. S.; Synth. Commun. 1998, $28,559$.

29. Silverstein, R. M.; Bassler, G. C.; Morrill, T. C.; Spectrometric Identification of Organic Compounds, $5^{\text {th }}$ ed.; John Wiley \& Sons: Singapore, 1991, p. 221.

30. Vaghei, R. G.; Tetrahedron Lett. 2003, 44, 7529.

31. Iskra, J.; Stavber, S.; Zupan, M.; Synthesis 2004, 1869.

32. Branystska, O. V.; Neumann, R.; J. Org. Chem. 2003, 68, 9510.

33. Aldrich Handbook of Fine Chemicals, Aldrich Chemical Co., http://www.sigmaaldrich.com, accessed in July 2011.

34. Yusubov, M. S.; Funk, T. V.; Chi, K.-W.; Cha, E. H.; Kim, G. M.; Kirschning, A.; Zhdankin, V. V.; J. Org. Chem. 2008, 73, 295.

35. Frisch, M. J.; Trucks, G. W.; Schlegel, H. B.; Scuseria, G. E.; Robb, M. A.; Cheeseman, J. R.; Scalmani, G.; Barone, V.; Mennucci, B.; Petersson, G. A.; Nakatsuji, H.; Caricato, M.; Li, X.; Hratchian, H. P.; Izmaylov, A. F.; Bloino, J.; Zheng, G.; Sonnenberg, J. L.; Hada, M.; Ehara, M.; Toyota, K.;
Fukuda, R.; Hasegawa, J.; Ishida, M.; Nakajima, T.; Honda, Y.; Kitao, O.; Nakai, H.; Vreven, T.; Montgomery Jr., J. A.; Peralta, J. E.; Ogliaro, F.; Bearpark, M.; Heyd, J. J.; Brothers, E.; Kudin, K. N.; Staroverov, V. N.; Kobayashi, R.; Normand, J.; Raghavachari, K.; Rendell, A.; Burant, J. C.; Iyengar, S. S.; Tomasi, J.; Cossi, M.; Rega, N.; Millam, J. M.; Klene, M.; Knox, J. E.; Cross, J. B.; Bakken, V.; Adamo, C.; Jaramillo, J.; Gomperts, R.; Stratmann, R. E.; Yazyev, O.; Austin, A. J.; Cammi, R.; Pomelli, C.; Ochterski, J. W.; Martin, R. L.; Morokuma, K.; Zakrzewski, V. G.; Voth, G.A.; Salvador, P.; Dannenberg, J. J.; Dapprich, S.; Daniels, A. D.; Farkas, O.; Foresman, J. B.; Ortiz, J. V.; Cioslowski, J.; Fox, D. J.; Gaussian 09, Revision A.1, Gaussian, Inc.: Wallingford CT, 2009.

36. Breneman, C. M.; Wiberg, K. B.; J. Comput. Chem. 1990, 11, 361.

37. Reiling, S.; Besnard, M.; Bopp, P. A.; J. Phys. Chem. A 1997, 101,4409 .

Submitted: July 29, 2011

Published online: November 22, 2011 